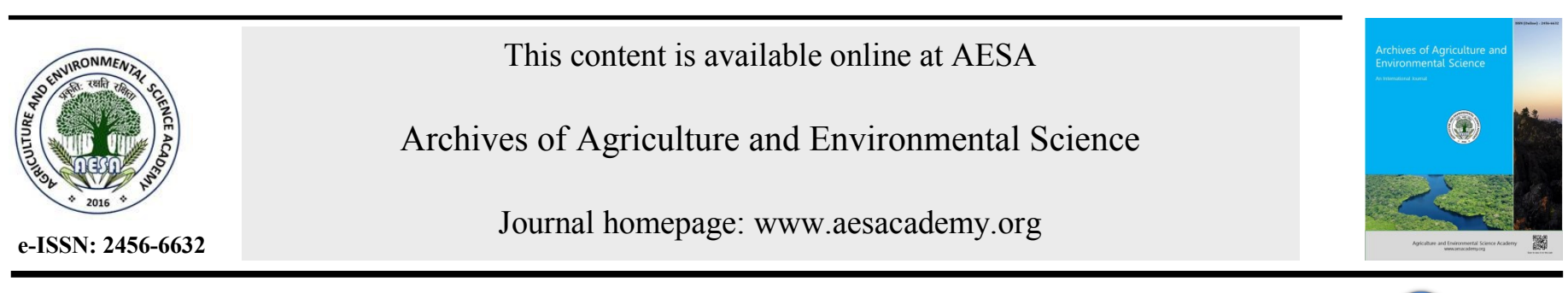

ORIGINAL RESEARCH ARTICLE

\title{
Spatial distribution of solid waste disposal sites in Allahabad city, Uttar Pradesh, India using GIS approach
}

\author{
Nitin Kamboj ${ }^{*}$ and Neeraj Pandey \\ Department of Zoology and Environmental Science, Gurukula Kangri Vishwavidyalyaya, Haridwar-249404 (Uttarakhand), \\ INDIA \\ *Corresponding author's E-mail: kambojgurukul@gmail.com
}

\section{ARTICLE HISTORY}

Received: 22 September 2017

Revised received: 27 October 2017

Accepted: 24 November 2017

\section{Keywords}

Geographic information system

Remote Sensing

Solid waste management

\begin{abstract}
The present investigation was conducted to study the spatial distribution of solid waste disposal sites in Allahabad city, Uttar Pradesh, India using GIS approach. In this investigation site determination for the transfer of strong waste is performed utilizing geographical information system (GIS), the analytical hierarchy process (AHP), and remote detecting strategies for the Allahabad city. In GIS, every single possible prerequisite are at first indicated, spatial information coordinated and overlaid and in view of the last yield got appropriate naturally kindhearted destinations for squander transfer are recognized. Analytical hierarchy process give a deliberate way to deal with evaluating and incorporating the effects of different variables, including a few levels for surveying and coordinating the effects of different components, including a few levels dependent and free, qualitative and quantitative data. Remote Sensing pictures and Survey of India topomaps were utilized to extricate data on badlands and other lands utilize highlights, geography, hydro-geomorphology, seepage, street systems and slant of the region. Various tools and software's were used for the study like Arc GIS 10.1 LIS III image, SRTM DATA, ERDAS imagine etc. The results of the present study indicated that maps of land use cover/land use change/ satellite imageries and GIS tool were benefited for characterizing appropriate plans and methodologies for effective solid waste management plan in metropolitan cities. Therefore, GIS tools, satellite imageries, maps must be considered for the implementation of solid waste management policies.
\end{abstract}

(C2017 Agriculture and Environmental Science Academy

Citation of this article: Kamboj, N. and Pandey, N. (2017). Spatial distribution of solid waste disposal sites in Allahabad city, Uttar Pradesh, India using GIS approach. Archives of Agriculture and Environmental Science, 2(4): 357-360, DOI: 10.26832/24566632.2017.020420

\section{INTRODUCTION}

India is the world's second greatest populated country after China with population of 1.21 billion (insights 2011) and that infers India contain $17.5 \%$ of the aggregate people, is a place that is known for physical grouped assortment, climatic assortment, geographic arranged assortment, ecological nice assortment, social grouped assortment, social arranged assortment and etymological grouped assortment (Al-Hanbali et al., 2011; Yadav, 2013). The yearly improvement rate of urban populace in India is $3.35 \%$ (Census of India, 2011). The degree of people living in urban zones has extended from $17.35 \%$ (1951) to $31.2 \%$ (2011) (Karadimas et al., 2004; Census, 2011; Yogeshwar, 2012). The quick and consistent advancement in urban masses prompts an enthusiastic augmentation in urban solid wastage, with a genuine monetary and biological impact. In case this situation isn't dealt with in a proper route inside time then it would be immediate more unfortunate results on an overall level and besides causing biological tainting and have ended up being persevering issues for mankind. In this manner solid waste organization (Solid waste management) is one of the major thing basic organizations to be given by metropolitan specialists in India, the current circumstance gives rather an ungraceful picture the extent that organization movement as affirm by nonappearance of attractive general waste organization instrument (Khajuria et al., 2011). Show level of organization in various urban reaches is low to the point that there is a hazard to the general prosperity particularly and normal quality when all is said in done (Akolkar, 2005; Shahabi, 2012). Strong squanders are the natural and inorganic waste materials, for example, item bundling, grass clippings, furniture, apparel, bottles, kitchen won't, paper, apparatuses, paint jars, batteries, and so forth., created in a general public, which don't for the most part convey any an incentive to the main user(s) (Kamboj and Choudhary, 2013). Strong waste administration has turned into a noteworthy test in urban regions all through the world. Without a successful and productive strong waste administration program, the waste created from different human exercises, both mechanical and local, can bring about wellbeing perils and negatively affect the earth and people. Geographic information system (GIS) may adequately be utilized to choose the best possible site areas arranged by their needs (Sharholy et al., 2007; Nishanth, 2010). The spatial information might be put away as various topical layers and controlled to determine new usable data utilizing the current 
ones in GIS. When all is said in done, GIS is intended to acknowledge extensive volumes of spatial information got from various sources and to effectively store, recover, control, examine them. Different fields including remote detecting, cadastral mapping, cartography, structural designing, geology, soil science, studying and photogrammetry can be utilized as a contribution to GIS (Idris et al., 2004; Sharholy et al., 2007; Suchitra, 2007; Sener, 2010). Aside from managing various given essential spatial substances and measures of their area in the earth space, it likewise manages a large group of nonspatial component of these elements (Nas et al., 2010; Nishanth, 2010). Subsequently, a GIS speaks to a personal computer based data framework for dealing with both spatial information and non-spatial information got from an assortment of sources. Further, GIS licenses not just the mechanized mapping or show of areas of highlights yet in addition give a social database ability to recording and breaking down expressive trademark about highlights. Information from the GIS might be recovered by determining either area or trait recovery criteria. Accordingly GIS can fill in as a proving ground for contemplating, arranging, ecological procedures, breaking down the after effects of patterns' expecting the conceivable consequences of arranging choices and administration of assets. The GIS may likewise be utilized for formative arranging in an area (Khajuria et al., 2011; Kumar, 2011; Chaudhary and Das, 2012; Mohammedshum, 2014). The use of present day strategy like GIS will help the organizers and leaders in accomplishing an adjusted advancement in Allahabad city. Squander administration is one of the most concerning issues confronted around the world. This is a direct result of the fast development in the populace and urbanization, which comes about into the decline of the non-inexhaustible assets and transfer of emanating and dangerous waste aimlessly posturing dangers to the presence of people. The adequacy of strong waste transfer relies on the choice of appropriate site and there are a few issues that have affect for site choice. Site choice is hence a standout amongst the most basic zones of metropolitan arranging including a multidisciplinary approach and an expansive range of thought (Chaudhary and Das, 2012; Mohammedshum, 2014). The after effect of the investigation can be exceptionally useful amid the acquisition procedure of transfer locales; that is, the concerned specialists can spare time and expenses related with assessment and assessment for bidders whose destinations are situated far outside the scope of conceivably distinguished territories. Keeping in view, the present investigation was carried out to study the spatial distribution of solid waste dumping sites in Allahabad city, Uttar

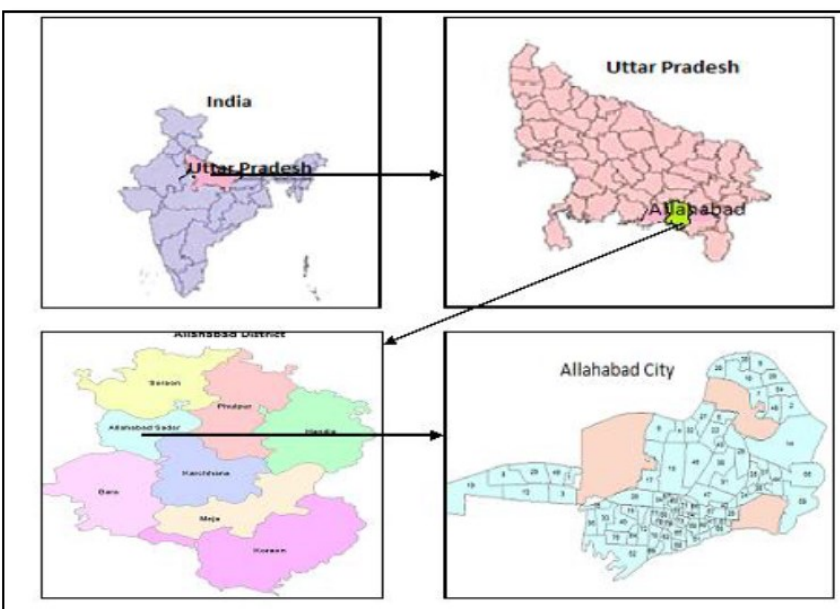

Figure 1. Geographical location of the study area.
Pradesh, India for the effective solid waste management policies using GIS approach.

\section{MATERIALS AND METHODS}

Study area description: Allahabad is a major city of Uttar Pradesh falls in the administrative headquarters of the Allahabad district (Figure 1). It is considered holy because the sacred rivers Ganga-Yamuna-Saraswati unite here. It is situated at $25.25^{\circ}$ North latitude and $81.58^{\circ}$ East longitude. It is the seventh most populous city of Uttar Pradesh and was ranked $130^{\text {th }}$ fastest-growing city in the world in 2011. The metropolitan city covers an area of $63.07 \mathrm{sq} \mathrm{km}$ and the population of the city as per census 2011 is $11,12,544$. The topography of Allahabad city is flat and the temperature varies between $47.8^{\circ} \mathrm{C}$ in summer to lowest $4.1^{\circ} \mathrm{C}$ in winter. The city receives on an average annual rainfall of $930 \mathrm{~mm}$.

Collection of data: For present study, LISS-III of year 2005 has been used. Resolution of image is 30 meter that obtained from NRSC, SRTM (DEM) of year 2005 has been used, resolution of which is 3 arc second $(90 \mathrm{~m})$, Esri's ArcGIS a geographical information system (GIS) for working with maps and geographic information, ERDAS IMAGINE is a remote sensing application with raster graphics editor abilities designed by ERDAS for geospatial applications, Land-use / land-cover map, road map, topographic map, drainage map, and other relevant maps were obtained from relevant agencies including Nagar Nigam Allahabad, Survey of India (Figure 2).

Data used: A number of digital data were used for the analysis. Most of the layers were available for the whole of Allahabad. Therefore, the layers had first to be clipped in the GIS to the extent of the Allahabad city. The projection of all layers had to be set to WGS_84 Map Grid to ensure consistency and enable the overlay of several layers.

Toposheet (Survey of India): For the present study Survey of India (SOI) topographical map G44P15 at the scale 1:50,000 have been used (Figure 2). From the Toposheet creates the shape file of road, river and railway network using the Arc GIS 10.1 software.

LISS-III Satellite image: For present study, LISS-III of year 2005 has been used. Resolution of image is 30 meter that obtained from NRSC (Figure 2).

Digital elevation model (SRTM data): For present study, SRTM (DEM) of year 2005 has been used. Resolution of this image is 3 arc second $(90 \mathrm{~m})$. SRTM data in 3 arc sec $(90 \mathrm{~m})$ resolution can be found in either 'research' or 'finished' grade (http://srtm.usgs.gov).

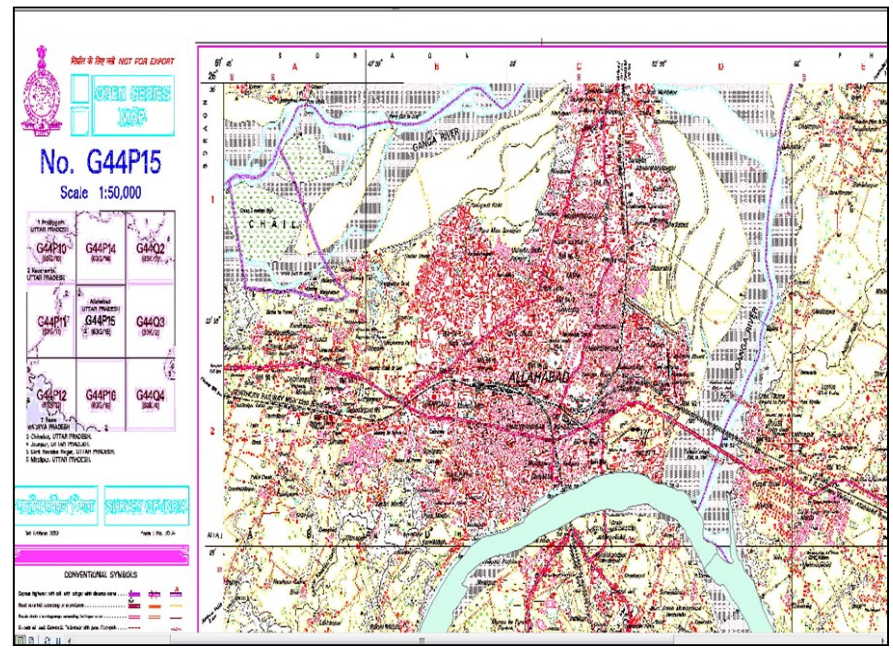

Figure 2. Toposheet of the Allahabad city (Source: Nagar Nigam Allahabad). 


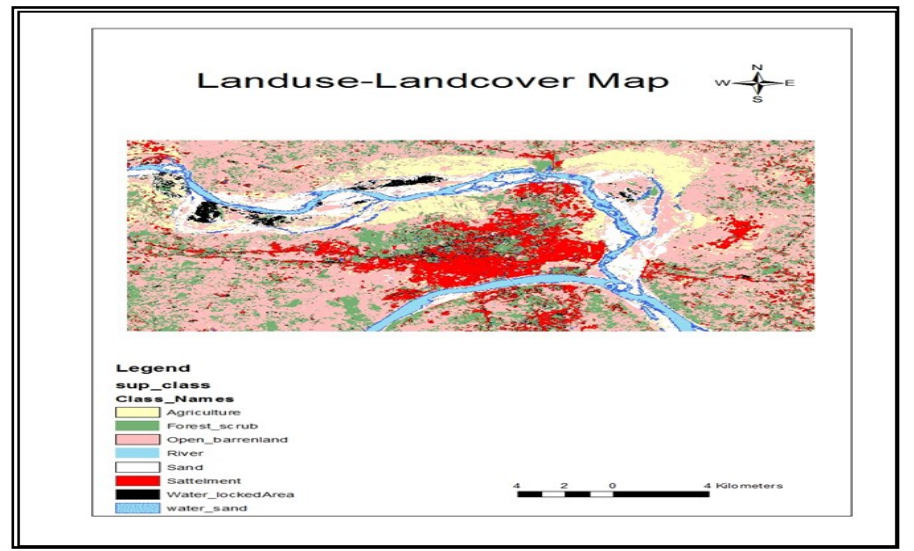

Figure 3. Land use-Land cover map of Allahabad city.

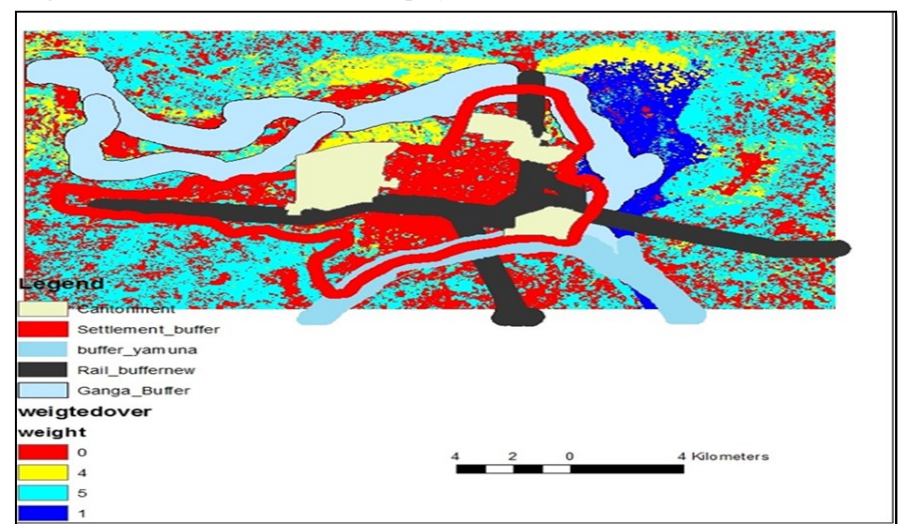

Figure 5. Site suitability map for waste disposal.

\section{RESULTS AND DISCUSSION}

The table 1 and figure 3, 4 and 5 describes various land use pattern and land cover scheme classification. It clearly indicated that open or barren land can only be used for the waste disposal using scientific measures. Most importantly the solid waste disposal sites must be far away from the water sources like rivers and lakes, agricultural land, forest land and residential areas. Akolkar (2005) also suggested the importance of land use cover for the effective management of solid waste. The present examination was intended to consider the criteria's impacting the propriety of a site for misuse organization, arrive use/arrive cover examination of study zone, develop an appropriate GIS show for site decision for dumping goals, dismember the diverse maps delivered using GIS show for site decision for brief exchange regions. In light of these objectives the basic conclusions are drawn from the present exami-

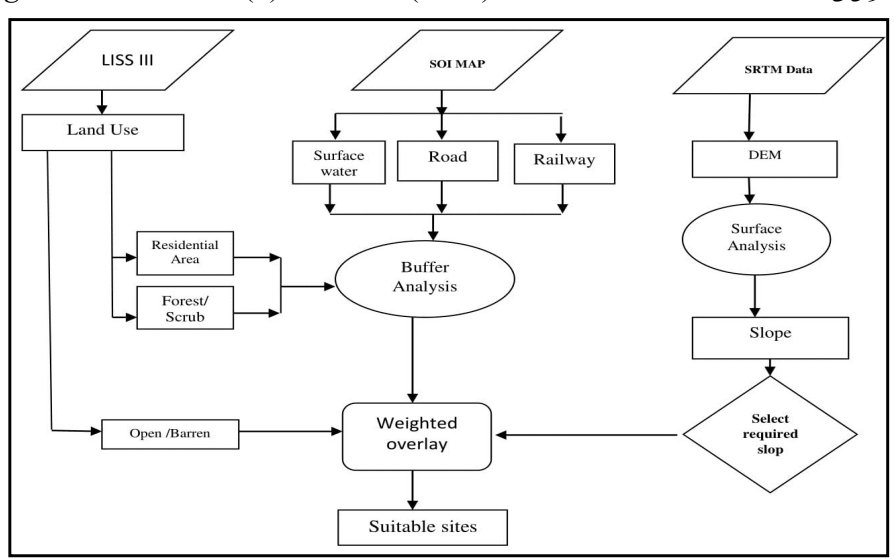

Figure 4. Flow chart for selection of suitable dumping site.

nation and are shown as the parts that can impact the sensibility of a site for dumping solid waste has been pondered are: site constrain, arrive cover, isolate from Airports, expel from surface water, adjacent geography, soils, climate, dubious zones, neighborhood generally differed vegetation, expel from normally delicate or protected regions expel from urban zones and people. The eventual outcomes of land use and arrive cover examination exhibit that ebb and flow arrive classes in the examination domain are: created arrive (Settlement), agribusiness arrive, sand, water, and timberland/spotless and open/ destroy arrive. Nas et al. (2010) also suggested the importance of GIS and multi-criteria evaluation for the selection of municipal solid waste (MSW) landfill site for Konya, Turkey.

Moreover, site suitability map for waste disposal (Figure 5) also benefited the municipal corporations and local governance for the effective utilization of resources. Khajuria et al. (2011) and Shahabi (2012) reported that site suitability map and GIS application were found helpful for estimating the current status of municipal solid waste management system. These results may be profitable for characterizing appropriate plans and methodologies with a specific end goal to achieve a balanced and reasonable progression in the zone. The site assurance is a critical propel when masterminding solid waste land application contrive. By using the support examination and weighted overlay technique a fitting site for dumping districts has been perceived and showed up in diagram. Khajuria et al. (2011) reported the current status of municipal solid waste management system in Chandigarh City, India using GIS tools. Yogeshwar (2012) and Yadav (2013) are also in favoured the use of GIS techniques and remote sensing in the effective solid waste management.

Table 1. Land use/ land cover classification scheme (Anderson et al., 1976).

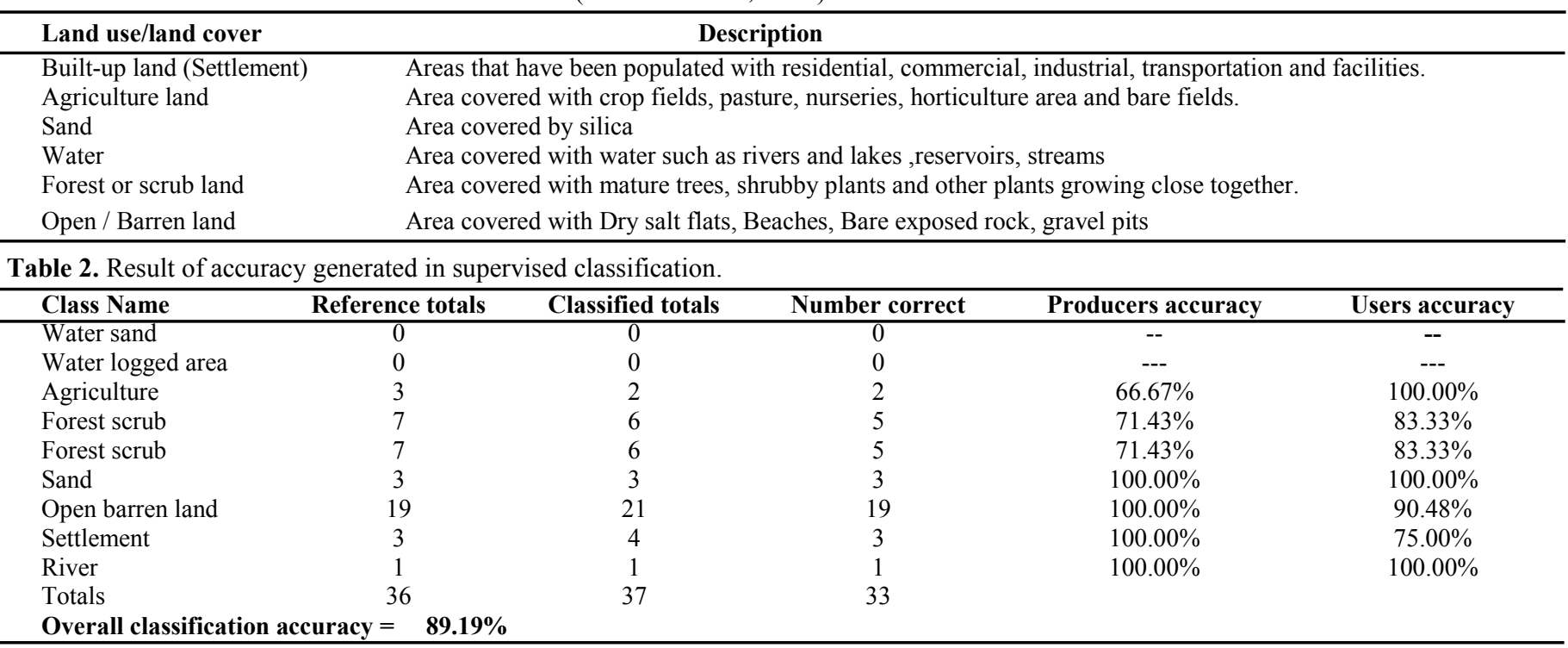




\section{Conclusions}

The present study concluded that GIS tools are very important for the selection of suitable sites for solid waste disposal. The results of the present study benefited for characterizing appropriate plans and methodologies for effective solid waste management plan in metropolitan cities. Therefore, GIS tools, satellite imageries, maps must be considered for the implementation of solid waste management policies.

Open Access: This is open access article distributed under the terms of the Creative Commons Attribution License, which permits unrestricted use, distribution, and reproduction in any medium, provided the original author(s) and the source are credited.

\section{REFERENCES}

Anderson, J. R., Hardy, E.E., Roach, J.T. and Witmer, R.E. (1976). A land use and land cover classification system for use with remote sensor data. Geological Survey Professional Paper 964, USGS, Reston, VA.

Akolkar, A.B. (2005). Status of solid waste management in India, implementation status of municipal solid wastes, management and handling rules 2000, Central Pollution Control Board, New Delhi.

Al-Hanbali, A., Alsaaideh, B. and Kondoh, A. (2011). Using GISbased weighted linear combination analysis and remote sensing techniques to select optimum solid waste disposal sites. Journal of Geographic Information System, 3: 267-278.

Chaudhary, S. and Das, S. (2012). GIS and remote sensing for landfill site selection- A Case study on Dharmanagar Nagar Panchayat. Journal of Environmental Science, Toxicology and Food Technology 1(2): 36-43.

Census of India (2011). Population of India. Retrieved from http:// censusindia.gov.in/

Idris, A., Inane, B., Hassan, M.N. (2004). Overview of waste disposal and landfills/dumps in Asian countries. Journal of Material Cycles and Waste Management, 6: 104-110.

Kamboj, N. and Choudhary, M. (2013). Impact of solid waste on ground water quality near Gazipur dumpling site, Delhi. Journal of Applied and Natural Sciences 5(2): 1-7.
Karadimas, N.V., Loumos, V. and Mavrantza, O. (2004). Quality of service ensuring in urban solid waste management, in Proceeding of the $2^{\text {nd }}$ International IEEE Conference on IntelligentSystems, Varna, Bulgaria, 288-292.

Khajuria, A., Matsui, T. and Machimura, T. (2011). GIS application for estimating the current status of municipal solid waste management system: Case study of Chandigarh City, India. Our Nature, 9: 26-33.

Kumar, S. (2011). Selection of a landfill site for solid waste management an application of AHP and spatial analyst tool. Journal of Indian Society of Remote Sensing, 41: 45-56.

Mohammedshum (2014). Application of geographic information system and remote sensing in effective solid waste disposal sites selection In Wukro Town, Tigray, Ethiopia. The International Archives of the Photogrammetry, Remote Sensing and Spatial Information Sciences, Xl-2: 115-119.

Nas, B., Cay, T., Iscan, F. and Berktay, A. (2010). Selection of MSW landfill site for Konya, Turkey using GIS and multi-criteria evaluation. Environmental Monitoring and Assessment, 160(14): 491-500.

Nishanth, T. (2010). Suitable site determination for urban solid waste disposal using GIS and remote sensing techniques in Kottayam Municipality. International Journal of Geomatics and Geosciences, 1(2): 197-210.

Sener, S. (2010). Solid waste disposal site with GIS and AHP methodology: A Case Study in Senirkent-Uluborlu (Isparta) Basin, Turkey. Journal of Environmental Monitoring Assessment (10):1010-1023.

Shahabi, H. (2012). Application of GIS Models in site selection of waste disposal in urban, area. Journal of Applied Physics, 1: 0107.

Sharholy, M., Ahmad, K. Vaishya, R.C. and Gupta, R.D. (2007). Municipal solid waste characteristics and management in Allahabad, India. Waste Management, 27(4): 490-496.

Suchitra, M. (2007). Outside: Burnt or buried, garbage needs land. Down To Earth, PP. 22-24.

Yadav, K. (2013). GIS based approach for site selection in waste management. International Journal of Environmental Engineering and Management, 4(5): 507-514.

Yogeshwar, S. (2012). Solid waste management of Kolar municipality using remote sensing and GIS Techniques. International Journal of Advance Technology \& Engineering Research, 2(1): 1-8. 